\title{
Analisis Health Belief Model dalam Perilaku Pencegahan Covid-19 pada Ibu Hamil
}

\author{
Analysis of Health Belief Model in Covid-19 Preventive Behaviour in Pregnant \\ Women
}

\author{
Ratna Diana Fransiska ${ }^{1 凶}$, Dian Kusumaningtyas², Kentri Anggarina Gumanti ${ }^{3}$
}

1,2,3Jurusan Kebidanan Fakultas Kedokteran Universitas Brawijaya

\begin{abstract}
ABSTRAK
Latar Belakang: Peningkatan kasus infeksi Covid-19 yang terus terjadi menimbulkan kekhawatiran, terutama pada ibu hamil yang termasuk dalam kelompok yang mudah terinfeksi. Pada ibu hamil, infeksi Covid-19 berisiko menyebabkan morbiditas dan mortalitas yang lebih buruk dibandingkan populasi umum. Oleh karena itu, ibu hamil perlu melakukan upaya pencegahan agar tidak terinfeksi. Perlu adanya perubahan perilaku untuk meningkatkan kesehatan dalam upaya pencegahan Covid-19. Tujuan: Mengetahui penerapan teori Health Belief Model dalam upaya mencegah transmisi Covid-19 pada ibu hamil di Kota Malang.

Metode: Penelitian analitik korelasional menggunakan pendekatan cross-sectional. Partisipan dipilih dengan menggunakan teknik simple random sampling dari 5 puskesmas di Kota Malang. Pengumpulan data dilaksanakan dari bulan November 2020 sampai dengan Januari 2021, dengan menggunakan kuesioner untuk mengukur Health Belief Model dan perilaku pencegahan Covid-19 pada ibu hamil.

Hasil: Persepsi kerentanan, persepsi keseriusan, isyarat untuk bertindak, dan persepsi manfaat memiliki pengaruh yang tidak signifikan. Persepsi hambatan dan self-efficacy mempunyai pengaruh signifikan pada perilaku ibu hamil di Kota Malang dalam pencegahan Covid-19.

Kesimpulan: Komponen health belief model saling berhubungan satu sama lain dalam mempengaruhi perilaku ibu hamil melakukan pencegahan Covid-19, meskipun tidak semua signifikan secara statistik. Untuk itu diperlukan intervensi untuk meningkatkan pengetahuan dan menciptakan kesadaran yang berkelanjutan untuk mencegah Covid-19.
\end{abstract}

Kata Kunci: Covid-19; Health Belief Model; ibu hamil

\section{ABSTRACT}

Background: The escalation in Covid-19 infection cases raises concerns especially in pregnant women as a part of the vulnerable group. Covid-19 infection in pregnant women has greater risk of morbidity and mortality compared to general population. Therefore, behavioral changes are needed to improve health in Covid-19 prevention.

Objective: To understand the application of the Health Belief Model theory in Covid-19 prevention behavior of pregnant women in Malang.

Methods: This wasa correlational analytic study with a cross-sectional approach. Participants were selected using a simple random sampling technique from 5 health centersin Malang. Data collection was carried out from November 2020 to January 2021, using a questionnaire to measure the Health Belief Model and a questionnaire to measure Covid-19 prevention behavior in pregnant women.

Results: Perceived vulnerability, perceived seriousness, perceived benefits, and cues to action hadno significant effect. Perceptions of barriers and perceptions of self-efficacy hada significant influence on the Covid-19 prevention behavior of pregnant women in Malang.

Conclusion: The components of the health belief model are interrelated with each other in influencing the behaviour of pregnant women in preventing Covid-19, although not all are statistically significant.Interventions are needed to increase public knowledge and create a sustainable awareness in Covid-19 prevention.

Keywords: Covid-19; Health Belief Model; pregnant women

凶Corresponding author: ratnadiana90@ub.ac.id

Diajukan 8 Juli 2021 Diperbaiki 18 Januari 2022 Diterima 17 Februari 2022

https://jurnal.ugm.ac.id/jkesvo Published online February 28, 2021 
PENDAHULUAN

Tahun 2020 diawali dengan munculnya wabah pneumonia yang berasal dari Wuhan, Provinsi Hubei, Cina yang sudah terdeteksi sejak akhir 2019 dan sangat cepat merebak ke berbagai belahan dunia. Penyebab wabah ini adalah Severe Acute Respiratory Syndrome Coronavirus-2 (SARS-CoV-2) sehingga disebut sebagai wabah Coronavirus Disease 2019 (Covid-19) (Susilo et al., 2020).

Sampai saat ini, virus ini sudah menjangkiti penduduk seluruh dunia. Terdapat lebih dari 100 negara dengan jumlah kasus 84.018 .950 orang dan 2.104.100 orang di antaranya meninggal dunia. Di Indonesia sendiri, penderita Covid-19 terus bertambah. Data yang diperoleh dari Komite Penanganan Covid19 pada tanggal 17 Juni 2021 didapatkan jumlah pasien terkonfirmasi positif 1.950.276 orang dan kasus meninggal 53.753 orang $(2,75 \%)$ (Satgas COVID-19, 2021).

Provinsi Jawa Timur menduduki peringkat ke-4 jumlah kasus Covid-19 terkonfirmasi paling banyak, dengan jumlah kasus sebanyak 159.059 kasus. Angka tersebut menyumbang 8,3\% dari keseluruhan kasus di Indonesia (Pemprov Jatim, 2021). Di Kota Malang, dari data yang diakses melalui situs Infocovid19.jatimprov.go.id, terdapat kasus terkonfirmasi positif Covid-19 sebanyak 6.865 orang dan 647 orang di antaranya meninggal dunia.

Peningkatan kasus yang terus terjadi tentu menimbulkan kekhawatiran pada masyarakat umum terutama ibu hamil sebagai bagian dari kelompok rentan. Ibu hamil memiliki risiko yang mungkin lebih besar dalam kejadian morbiditas, penyakit berat, dan mortalitas apabila dikomparasikan dengan populasi umum (PP POGI, 2020). Hal tersebut terjadi sebagai akibat dari berbagai perubahan yang terjadi dalam tubuh dan sistem daya tahan tubuh dari ibu hamil.

Gangguan dan infeksi saluran pernafasan dapat memberikan efek yang lebih mengkhawatirkan terhadap ibu hamil. Hal tersebut dapat terjadi karena pada kehamilan terjadi peninggian diafragma, penekanan pada rongga thorax, dan penurunan volume paru sehingga menyebabkan shortness of breath. Kemampuan tubuh untuk membersihkan sekret saluran pernapasan juga menurun, serta meningkatnya resiko infeksi yang berat (Nurdianto et al., 2020).

Perubahan sistem imunologi tubuh selama kehamilan menjadikan ibu hamil lebih rentan terhadap infeksi. Oleh karena itu, ibu hamil perlu menerapkan beragam tindakan pencegahan agar terlindungi dari Covid-19. Tindakan pencegahan Covid-19 pada ibu hamil meliputi universal precaution.

Penggunaan masker, lebih sering mencuci tangan menggunakan sabun dan air atau antiseptik berbasis alkohol (hand sanitizer), menjaga jarak sosial yang aman setidaknya 1 meter, dan menghindari tempat ramai yang memungkinkan orang berkerumun merupakan perilaku yang perlu diterapkan tidak hanya oleh ibu hamil, tetapi seluruh masyarakat di masa pandemi ini. Penting juga untuk menjaga dan memperkuat kekebalan tubuh dengan menerapkan pola hidup bersih dan sehat (Coronavirus Disease (COVID-19), 2020).

Berdasarkan penelitian Briet et al., (2020) menunjukkan pada 55 kasus kehamilan yang terjangkiti Covid-19, telah lahir sebanyak 46 neonatus yang tidak memperlihatkan tanda terinfeksi virus SARS-CoV-2 yang terjadi dari ibu ke janinnya atau secara vertikal. Beberapa tes yang dijalankan membuktikan hal ini, yaitu antara lain hasil swab dari tenggorokan bayi yang baru lahir dengan hasil negatif, hasil pemeriksaan ASI, hasil pemeriksaan cairan amniotik, dan cord blood.

Fase awal kehamilan diketahui terdapat potensi infeksi SARS-CoV-2 yang dapat mempengaruhi organogenesis dan perkembangan janin. Jika kasus terjadi 
dalam waktu yang semakin dini, akan semakin besar risiko abortus. Hal ini disebabkan proses penyaluran oksigen dan nutrisi melewati plasenta pada pertumbuhan janin yang terganggu karena menurunnya kondisi ibu. (Briet et al., 2020).

Terjadinya transmisi Covid-19 dalam usia kehamilan yang lebih tua dapat menyebabkan berbagai dampak. Sesuai hasil penelitian Yang et al. (2020), dari tujuh bayi baru lahir yang dilahirkan oleh ibu terinfeksi SARS-CoV-2, didapatkan 4 bayi lahir prematur pada usia kehamilan antara 36 minggu hingga 37 minggu dan 3 bayi lahir cukup bulan dengan rata-rata berat lahir $2.096 \pm 660 \mathrm{~g}(1.880-3.800 \mathrm{~g})$. Secara keseluruhan bayi lahir tidak terdapat bayi yang memiliki tanda-tanda asfiksia sehingga tidak ada bayi yang terkonfirmasi positif berdasarkan tes RTPCR (Yang et al., 2020).

Mengingat dampak buruk yang mungkin terjadi baik pada ibu maupun janin, maka ibu hamil harus berupaya dalam pencegahan infeksi virus ini. Dalam upaya mencegah suatu penyakit harus terdapat perilaku yang berubah dari individu dalam menjaga kesehatan (Nugrahani et al., 2017). Ada beragam teori yang diterapkan menjadi landasan perubahan perilaku kesehatan pada individu, seperti teori Health Belief Model.

Menurut teori yang dikembangkan oleh Stretcher \& Rosenstock ini disebutkan bahwa keyakinan seseorang akan ancaman suatu penyakit, persepsi tentang manfaat, dan hambatan yang terkait dengan perilaku kesehatan akan memprediksi kemungkinan individu mengadopsi perilaku kesehatan tersebut atau tidak (LaMorte, 2019). Oleh sebab itu, peneliti ingin melihat komponen dari teori Health Belief Model yang berperan besar dalam perilaku pencegahan Covid-19 pada ibu hamil yang terdapat di area Kota Malang.

\section{METODE}

Desain pada penelitian ini adalah analitik korelasional dengan pendekatan cross-sectional. Partisipan dari penelitian ini adalah $120 \mathrm{ibu}$ hamil di wilayah Kota Malang dengan kriteria inklusi kehamilan normal dan tidak sedang terkonfirmasi positif Covid-19. Pelaksanaan penelitian dimulai dari November 2020 sampai Januari 2021.

Partisipan diambil menggunakan teknik simple random sampling dari 5 puskesmas yang berada di wilayah Kota Malang. Dari masing-masing puskesmas akan dipilih 24 ibu hamil secara acak yang telah diberikan informasi mengenai penelitian dan bersedia menjadi responden penelitian dengan mengisi kuesioner baik secara online maupun offline.

Penggunaan instrumen dalam penelitian ini, yaitu 2 buah kuesioner, yang merupakan kuesioner untuk mengukur Health Belief Model yang meliputi 6 komponen dan kuesioner untuk mengukur perilaku pencegahan Covid-19 pada ibu hamil. Kuesioner tentang Health Belief Model terdiri dari 24 pernyataan yang harus dijawab oleh responden dengan jawaban kategori jawaban sangat setuju sampai dengan sangat tidak setuju.

Seluruh pernyataan pada kuisioner ini meliputi 6 komponen health beliefmodel, yaitu persepsi kerentanan, persepsi keseriusan, persepsi manfaat, persepsi hambatan, isyarat untuk bertindak, dan self-efficacy. Kuesioner perilaku pencegahan Covid-19 adalah gambaran sikap, pengetahuan, serta tindakan yang menunjukkan upaya untuk mencegah terinfeksi virus Covid-19 yang dilakukan oleh ibu hamil terdiri dari 24 pernyataan dengan 5 kategori jawaban yaitu "Selalu" sampai dengan "Tidak pernah".

Semua instrumen yang digunakan telah dilakukan uji validitas dan reliabilitas oleh peneliti. Pengumpulan data menggunakan instrumen ini dilaksanakan secara online dengan 
pengisian kuesioner melalui google form maupun offline dengan pengisian kuesioner secara langsung. Hasil dari pengisian kuesioner telah ditabulasi dan dilakukan uji statistik secara multivariat menerapkan analisis regresi linier ganda menggunakan bantuan software SPSS.

\section{HASIL DAN PEMBAHASAN}

Berdasarkan data pada Tabel 1 dapat diketahui bahwa mayoritas responden berada pada kelompok usia 26-30 tahun. Jumlah responden paling sedikit berada pada kelompok usia di bawah 20 tahun, dan diikuti kelompok usia di atas 40 tahun. Dari tingkat pendidikan, dapat diketahui bahwa sebagian besar responden mendapatkan pendidikan hingga jenjang SMA, sedangkan jumlah responden paling sedikit berada pada jenjang SD.

Distribusi frekuensi paritas responden, jumlah terbanyak adalah multipara, sedangkan jumlah responden paling sedikit berada pada kategori grandemultipara. Berdasarkan pekerjaan, diketahui bahwa mayoritas responden merupakan ibu rumah tangga, sedangkan jumlah responden paling sedikit berstatus sebagai mahasiswa dan PNS.

Tabel 1. Karakteristik Responden Penelitian

\begin{tabular}{|c|c|c|c|}
\hline No & Karakteristik & Frekuensi & $\%$ \\
\hline \multirow[t]{7}{*}{1} & Usia & & \\
\hline & a. 20 tahun & 1 & $1 \%$ \\
\hline & b. $21-25$ tahun & 28 & $23 \%$ \\
\hline & c. $26-30$ tahun & 49 & $41 \%$ \\
\hline & d. $31-35$ tahun & 26 & $22 \%$ \\
\hline & e. $36-40$ tahun & 13 & $11 \%$ \\
\hline & f. $>40$ tahun & 3 & $2 \%$ \\
\hline \multirow[t]{7}{*}{2} & Pendidikan & & \\
\hline & a. SD & 5 & $4 \%$ \\
\hline & b. SMP & 7 & $6 \%$ \\
\hline & c. SMA & 62 & $52 \%$ \\
\hline & d. D1/D3 & 6 & $5 \%$ \\
\hline & e. D4/S1 & 30 & $25 \%$ \\
\hline & f. S2 & 10 & $8 \%$ \\
\hline \multirow[t]{4}{*}{3} & Paritas & & \\
\hline & a. Primipara & 41 & $34 \%$ \\
\hline & b. Multipara & 74 & $62 \%$ \\
\hline & c. Grandemultipara & 5 & $4 \%$ \\
\hline \multirow[t]{6}{*}{4} & Pekerjaan & & \\
\hline & a. IRT & 69 & $58 \%$ \\
\hline & b. Karyawan & 36 & $30 \%$ \\
\hline & c. Mahasiswa & 3 & $2 \%$ \\
\hline & d. PNS & 3 & $2 \%$ \\
\hline & e. Wiraswasta & 9 & $8 \%$ \\
\hline
\end{tabular}

Diketahui dari Tabel 2 bahwa rata-rata skor perilaku pencegahan Covid-19 pada ibu hamil adalah 100,72 dari rentang 24120, dengan simpangan deviasi sebesar 8,120 . Rata-rata skor persepsi kerentanan adalah 10,32 dari rentang 4-16.

Rata-rata skor persepsi keseriusan adalah 16,38 dari rentang 5-20. Rata-rata rentang skor manfaat adalah 10,01 dari rentang 3-12. Rata-rata rentang skor hambatan adalah 11,71 dari rentang 4-16. Rata-rata rentang skor isyarat untuk bertindak adalah 14,20 dari rentang 4-16. Rata-rata skor self-efficacy adalah 13,68 dari rentang 4-16.

Tabel 2. Deskriptif Statistik Variabel Penelitian

\begin{tabular}{clccc}
\hline No & \multicolumn{1}{c}{ Variabel } & Mean & SD & N \\
\hline 1 & Perilaku pencegahan & 100,72 & 8,120 & 120 \\
& Covid-19 & & & \\
2 & Persepsi kerentanan & 10,32 & 2,580 & 120 \\
3 & Persepsi keseriusan & 16,38 & 2,447 & 120 \\
4 & Persepsi manfaat & 10,01 & 1,520 & 120 \\
5 & Persepsi hambatan & 11,71 & 2,228 & 120 \\
6 & Isyarat untuk & 14,20 & 1,757 & 120 \\
& bertindak & & & \\
7 & Self-efficacy & 13,68 & 2,103 & 120 \\
\hline
\end{tabular}

Dari Tabel 3 didapatkan hasil bahwa nilai signifikan value $F$ test $<0,05$ yaitu nilai Sig 0,000, yang berarti bahwa keseluruhan variabel independen dari komponen Health Belief Modelmempunyai hubungan linier dengan variabel dependen. Secara bersama-sama persepsi keseriusan, persepsi kerentanan, persepsi hambatan, persepsi manfaat, isyarat dalam bertindak dan self-efficacy berpengaruh pada perilaku ibu hamil dalam pencegahan Covid-19.

Tabel 3. Hasil Uji Statistik ANOVA $^{a}$

\begin{tabular}{llccccc}
\hline No & Model & $\begin{array}{c}\text { Sum of } \\
\text { Squares }\end{array}$ & df & $\begin{array}{c}\text { Mean } \\
\text { Square }\end{array}$ & F & Sig. \\
\hline 1 & Regression & 1987,554 & 6 & 331,25 & 6,389 & ,000 \\
& Residual & 5858,813 & 113 & 9 & & \\
& Total & 7846,367 & 119 & 51,848 & \\
\hline a. Dependent Variable: Perilaku Pencegahan Covid-19 \\
b. Predictors: (Constant), Self Efficacy, Persepsi \\
\multicolumn{4}{l}{ Kerentanan, Persepsi Hambatan, Persepsi Manfaat, } \\
Persepsi Keseriusan, Isyarat untuk bertindak
\end{tabular}

Berdasarkan Tabel 4 didapatkan hasil bahwa secara individu, hubungan masingmasing variabel independen dengan 
variabel dependen dapat dilihat dari nilai $p$-value t-test. Jika nilai $p$-value t-test $<0,05$ pada taraf signifikasi $95 \%$, hipotesis nol ditolak yang artinya ada hubungan antara variabel independen dengan dependen.

Nilai p-value t-test yang $<0,05$ adalah variabel persepsi hambatan dan selfefficacy. Artinya, secara individu, persepsi hambatan dan self efficacy mempunyai pengaruh signifikan pada perilaku pencegahan Covid-19 pada ibu hamil (Tabel 3). Variabel lain yang meliputi persepsi keseriusan, persepsi kerentanan, persepsi manfaat dan isyarat untuk bertindak masing-masing memiliki hubungan yang tidak signifikan terhadap perilaku pencegahan Covid-19 pada ibu hamil.

Tabel 4. Hasil Uji Statistik $\mathbf{t}$

\begin{tabular}{|c|c|c|c|c|c|c|c|c|c|c|}
\hline \multirow{3}{*}{ No } & \multirow{3}{*}{ Model } & \multicolumn{7}{|c|}{ Coefficients $^{a}$} & & \\
\hline & & \multicolumn{2}{|c|}{$\begin{array}{l}\text { Unstandardized } \\
\text { Coefficients }\end{array}$} & \multirow{2}{*}{$\begin{array}{c}\begin{array}{c}\text { Standardized } \\
\text { Coefficients }\end{array} \\
\text { Beta }\end{array}$} & & \multirow{2}{*}{ Sig. } & \multicolumn{2}{|c|}{$\begin{array}{c}95,0 \% \text { Confidence } \\
\text { Interval for } B\end{array}$} & \multicolumn{2}{|c|}{$\begin{array}{c}\text { Collinearity } \\
\text { Statistics }\end{array}$} \\
\hline & & B & $\begin{array}{l}\text { Std. } \\
\text { Error }\end{array}$ & & & & $\begin{array}{l}\text { Lower } \\
\text { Bound }\end{array}$ & $\begin{array}{l}\text { Upper } \\
\text { Bound }\end{array}$ & Tolerance & VIF \\
\hline 1 & Constant & 69,910 & 6,114 & & 11,434 & 0,000 & 57,797 & 82,023 & & \\
\hline 2 & $\begin{array}{l}\text { Persepsi } \\
\text { kerentanan }\end{array}$ & $-0,185$ & 0,286 & $-0,059$ & $-0,646$ & 0,519 & $-0,751$ & 0,382 & 0,801 & 1,249 \\
\hline 3 & $\begin{array}{l}\text { Persepsi } \\
\text { keseriusan }\end{array}$ & 0,286 & 0,351 & 0,086 & 0,816 & 0,416 & $-0,409$ & 0,982 & 0,590 & 1,694 \\
\hline 4 & $\begin{array}{l}\text { Persepsi } \\
\text { manfaat }\end{array}$ & $-0,533$ & 0,557 & $-0,100$ & $-0,956$ & 0,341 & $-1,637$ & 0,572 & 0,607 & 1,648 \\
\hline 5 & $\begin{array}{l}\text { Persepsi } \\
\text { hambatan }\end{array}$ & 0,937 & 0,355 & 0,257 & 2,636 & 0,010 & 0,233 & 1,641 & 0,695 & 1,439 \\
\hline 6 & $\begin{array}{l}\text { Isyarat untuk } \\
\text { bertindak }\end{array}$ & 0,402 & 0,590 & 0,087 & 0,681 & 0,497 & $-0,768$ & 1,572 & 0,405 & 2,469 \\
\hline 7 & Self-efficacy & 1,219 & 0,457 & 0,316 & 2,665 & 0,009 & 0,313 & 2,126 & 0,471 & 2,124 \\
\hline a. De & pendent Variab & erilaku & egaha & vid-19 & & & & & & \\
\hline
\end{tabular}

\section{PEMBAHASAN}

Responden dalam penelitian ini adalah ibu hamil, sebagian besar tidak dalam usia yang menjadikan kehamilannya berisiko. Hal tersebut berdasarkan anjuran Kementerian Kesehatan Republik Indonesia (2014), yaitu agar kehamilan tidak berisiko, usia ibu hamil dianjurkan lebih dari 20 tahun dan kurang dari 35 tahun.

Banyak penelitian yang menyebutkan bahayanya kehamilan pada usia berisiko. Londero et al. (2019) dalam penelitiannya menyatakan bahwa usia ibu di atas 40 tahun merupakan faktor risiko independen untuk kelahiran prematur, gestational diabetes mellitus, operasi Caesar, presentasi janin abnormal, dan fetal periventricular leucomalacia.

Masih dari penelitian Londero et al. (2019), pada ibu yang lebih muda, gangguan kehamilan yang mungkin dihadapi mayoritas berhubungan dengan ketidakmatangan organ reproduksi dan sistem imun. Usia ibu yang kurang dari 17 tahun atau melewati usia 40 tahun merupakan faktor risiko independen untuk neonatal intraventicular hemorrhage grade 3 atau 4 (Londero et al., 2019).

Responden dalam penelitian ini mayoritas memiliki tingkat pendidikan yang mencukupi. Sebagian besar responden telah memenuhi setidaknya 12 tahun wajib belajarnya, yaitu minimal sampai dengan SMA sesuai dengan Peraturan Pemerintah Republik Indonesia Nomor 47 Tahun 2008 Tentang Wajib Belajar.

Tingkat pengetahuan wanita hamil berhubungan dengan tingkat komitmen mereka terhadap upaya mendapatkan pemahaman yang lebih baik tentang kesehatan mereka, tanggung jawab mereka terhadap janin mereka, dan upaya memerangi pandemi ini. Bertambah tingginya tingkat pendidikan mereka, memperbesar kemungkinan mereka untuk memiliki komitmen yang lebih kuat 
(Carolina Awad et al., 2020).

Sebagian besar responden sudah pernah melahirkan 2 sampai dengan 4 kali. Selebihnya adalah responden dengan kehamilan pertama atau primipara dan sangat sedikit grandemultipara atau kehamilan lebih dari 4 kali.

Keseluruhan data tersebut menunjukkan bahwa mayoritas responden memiliki kemungkinan rendah terhadap terjadinya kehamilan berisiko. Menurut penelitian Pontoh (2016) sebagian besar kehamilan berisiko tinggi dialami oleh ibu hamil grandemultipara, berusia lebih dari 35 tahun, dan berpendidikan dasar.

Hampir seluruh responden berada pada rentang usia produktif, yaitu 15 sampai dengan 64 tahun. Rentang usia tersebut merupakan rentang usia legal dan umum bagi seseorang untuk memiliki pekerjaan.

Ibu rumah tangga mendominasi jenis pekerjaan yang dimiliki oleh responden (Badan Pusat Statistik, 2019). Hal tersebut berlawanan dengan data yang dilaporkan oleh Kementerian Pemberdayaan Perempuan dan Perlindungan Anak (2018) yang menyebutkan bahwa di Indonesia, perempuan yang berusia 15 tahun ke atas sebagian besar, yaitu sebanyak 48,12\% adalah wanita yang bekerja.

Jumlah tersebut sedikit lebih tinggi daripada perempuan yang mengurus rumah tangga, yaitu sebesar 37,86\%. Namun, angka tersebut masih 10 kali lebih besar bila dibanding jumlah laki-laki yang mengurus rumah tangga, yang hanya sebesar 3,65\% (Hakiki \& Supriyanto, 2018).

Glanz et al. (2008) yang dikutip dalam penelitian Yehualashet et al. (2021), menyatakan Health Belief Model menyiratkan bahwa persepsi individu tentang kerentanannya terhadap suatu penyakit (persepsi kerentanan) melekat pada keyakinannya bahwa penyakit tersebut memiliki konsekuensi yang berpotensi serius (persepsi keseriusan). Persepsi kerentanan yang melekat pada persepsi keseriusan tersebut dapat diartikan sebagai ancaman yang dirasakan yang mengarahkan kepada perilaku seperti melakukan upaya pencegahan dan pemeriksaan (Glanz et al., 2008).

Persepsi kerentanan yang ditunjukkan oleh penelitian ini, memiliki pengaruh terhadap perilaku ibu hamil dalam pencegahan Covid-19, tetapi tidak signifikan. Pernyataan tersebut tidak sesuai dengan penelitian sebelumnya oleh Aghababaei et al. (2020) yang meneliti terkait persepsi kerentanan dengan perilaku kesehatan ibu hamil. Dalam penelitian tersebut menyatakan persepsi kerentanan memiliki pengaruh yang signifikan terhadap upaya pencegahan Covid-19 pada ibu hamil.

Penelitian lain menyatakan bahwa persepsi kerentanan merupakan penentu penting dari perilaku kesehatan, tetapi tetap dapat berubah tergantung dari karakteristik masing-masing jenis persepsi kerentanan dan tingkat akurasi dari persepsi tersebut (Ferrer \& Klein, 2015). Aenishaenslin et al., (2015) dalam penelitiannya yang dikutip oleh Aghababaei et al. (2020) menyatakan persepsi kerentanan sering dikatakan memiliki keterkaitan yang positif dengan perilaku pencegahan.

Namun, dalam beberapa kasus sering ditemukan juga interaksi negatif dengan perilaku pencegahan. Interaksi negatif yang dimaksud, misalnya ketika persepsi risiko tinggi, tetapi peluang keberhasilannya sangat kecil, kemungkinan penerapan perilaku pencegahan menjadi berkurang (Aghababaei et al., 2020).

Persepsi keseriusan yang dalam hasil penelitian ini menunjukkan pengaruh yang tidak signifikan terhadap perilaku ibu hamil dalam pencegahan Covid19.Pernyataan berbeda disampaikan dalam penelitian Khazaeian \& Khazaeian (2020), persepsi keseriusan disebutkan sebagai salah satu variabel yang secara signifikan berpengaruh terhadap perilaku ibu hamil dalam menghadapi Covid-19. 
Dikatakan juga bahwa orang dengan tingkat persepsi keseriusan yang tinggi, lebih cenderung melakukan tindakan pencegahan terhadap penyakit menular. Perbedaan hasil penelitian ini dapat dimungkinkan terjadi karena adanya perbedaan karakteristik demografi, usia, tingkat pengetahuan, maupun faktor lain (S Khazaeian et al., 2020).

Hasil dari penelitian ini juga menunjukkan skor persepsi kerentanan dan persepsi keseriusan yang tinggi $(10,32$ dari rentang $4-16$ dan 16,38 dari rentang 5 -20). Persepsi keseriusan dan persepsi kerentanan memiliki pengaruh penting dalam perilaku pencegahan Covid-19 pada ibu hamil, namun juga berpotensi meningkatkan resiko terjadinya depresi maupun kecemasan (Mo et al., 2021).

Artinya, makin tinggi persepsi kerentanan dan persepsi keseriusan seseorang, maka orang tersebut lebih mungkin untuk melakukan tindakan pencegahan. Akan tetapi, orang tersebut juga lebih berisiko untuk mengalami depresi maupun kecemasan.

Persepsi hambatan menurut hasil penelitian ini berpengaruh secara signifikan terhadap perilaku ibu hamil dalam pencegahan Covid-19. Barakat \& Kasemy (2020) dalam penelitiannya menyebutkan bahwa persepsi hambatan memiliki keterkaitan negatif dengan perilaku pencegahan infeksi Covid-19.

Makin rendah persepsi hambatan yang dimiliki individu, makin besar kemungkinan individu tersebut untuk menerapkan perilaku pencegahan. Persepsi hambatan merupakan komponen penting dan efektif dari Health Belief Model karena individu harus dapat mengambil kendali atas hambatan perilaku terlebih dahulu sebelum akhirnya dapat terlibat dalam perilaku pencegahan (Barakat \& Kasemy, 2020).

Persepsi manfaat menurut penelitian ini memiliki pengaruh terhadap perilaku ibu hamil dalam pencegahan Covid-19, tetapi tidak signifikan. Berbeda dengan penelitian sebelumnya oleh Mirzaei et al. (2021) yang menyatakan bahwa persepsi manfaat bersama dengan persepsi selfefficacy secara signifikan berpengaruh terhadap perilaku pencegahan Covid-19.

Hasil penelitian ini menunjukkan responden memiliki skor rata-rata persepsi manfaat cenderung tinggi $(10,01$ dari rentang 3-12), menandakan persepsi manfaat yang dimiliki cukup kuat (Mirzaei et al., 2021). Penelitian lain menyatakan adanya persepsi yang kuat akan manfaat dari upaya pencegahan seperti mencuci tangan secara teratur, menggunakan alat pelindung diri seperti masker dan sarung tangan sekali pakai, dapat menjadi motivasi yang kuat bagi individu untuk menerapkan perilaku pencegahan Covid-19 (Shahnazi et al., 2020).

Menurut Glanz et al. (2008) dalam Yehualashet et al. (2021) bahwa jika perilaku baru seperti pencegahan atau pemeriksaan dipercaya memiliki manfaat (persepsi manfaat) yang lebih besar daripada hambatan yang dirasakan seseorang (persepsi hambatan), dia lebih mungkin untuk menerapkan perilaku baru tersebut. Hasil penelitian ini menunjukkan hal yang selaras dengan pernyataan tersebut.

Skor persepsi manfaat yang dimiliki oleh responden lebih tinggi daripada skor persepsi hambatan (11,71 dari rentang 416). Hal tersebut menandakan bahwa responden lebih mungkin menerapkan perilaku pencegahan Covid-19.

Pernyataan tersebut juga didukung oleh Mengesha Yalew et al. (2021) yang dalam penelitiannya menyatakan bahwa responden yang memiliki persepsi hambatan rendah 3,17 kali lebih mungkin memiliki respons perilaku yang baik terhadap tindakan pencegahan Covid-19 daripada responden dengan persepsi hambatan yang tinggi. Oleh karena itu, tingkat kepatuhan terhadap perilaku pencegahan dapat ditingkatkan dengan mengurangi persepsi hambatan. 
Persepsi self-efficacy secara signifikan berpengaruh terhadap perilaku ibu hamil dalam pencegahan Covid-19, menurut hasil penelitian ini. Pernyataan tersebut didukung oleh Yehualashet et al. (2021) dalam penelitiannya yang menyatakan bahwa persepsi self-efficacy menjadikan seseorang 77\% lebih mungkin mematuhi langkah-langkah pencegahan Covid-19.

Skor rata-rata persepsi self-efficacy yang dimiliki oleh responden dalam penelitian ini menunjukkan angka yang tinggi (13,68 dari rentang 4-16). Persepsi self-efficacy yang kuat merupakan komponen penting untuk melemahkan persepsi hambatan dan merupakan variabel yang penting dalam upaya penerapan perilaku pencegahan Covid-19 (Shahnazi et al., 2020).

Persepsi self-efficacy didefinisikan oleh Glanz et al. (2008) yang dikutip dalam penelitian Shahnazi et al. (2020) sebagai tingkat kepercayaan diri seseorang dalam mengambil kendali atas hambatan yang dihadapinya dalam menerapkan perilaku sehat. Menurut Health Belief Model, individu harus memiliki tingkat selfefficacy yang sesuai untuk mengatasi hambatan perilaku. Adanya peningkatan persepsi efikasi diri merupakan faktor penting dalam mengatasi hambatan yang dirasakan, dan merupakan variabel yang efektif untuk terlibat dalam perilaku pencegahan Covid-19 (Barakat \& Kasemy, 2020).

Isyarat untuk bertindak yang dimiliki responden dalam penelitian ini cenderung tinggi (14,20 dari rentang 4-16), menandakan banyaknya faktor dorongan internal maupun eksternal untuk melakukan upaya pencegahan Covid-19. Glanz et al. (2008) yang dikutip dalam penelitian Yehualashet et al. (2021) menyatakan bahwa isyarat untuk bertindak didefinisikan sebagai peristiwa, orang atau hal yang mendorong seseorang untuk mengubah perilakunya, termasuk keluarga, teman, media, dan penyedia layanan kesehatan.
Variabel lain yang mungkin mempengaruhi adalah jenis kelamin, usia, etnis, sosial ekonomi, kepribadian, pengetahuan dan motivasi. Isyarat untuk bertindak, menurut penelitian ini, merupakan variabel yang mempengaruhi perilaku ibu hamil dalam pencegahan Covid-19, tetapi tidak signifikan.

Selaras dengan pernyataan penelitian sebelumnya yang dilakukan oleh Shahnazi et al. (2020), isyarat untuk bertindak berpengaruh terhadap perilaku pencegahan Covid-19. Namun, pengaruh isyarat untuk bertindak tidak lebih signifikan daripada faktor lain, seperti jenis kelamin, tempat tinggal, persepsi hambatan, dan persepsi self-efficacy.

\section{PENUTUP}

\section{Kesimpulan}

Masing-masing komponen dari Health Belief Model berpengaruh terhadap perilaku ibu hamil dalam pencegahan Covid-19. Meskipun tidak semuanya berpengaruh secara signifikan, tetapi mereka saling berhubungan. Jika seseorang memiliki persepsi kerentanan dan persepsi keseriusan terhadap kondisi kesehatannya, yang kemudian didukung dengan adanya isyarat untuk bertindak dan persepsi manfaat yang lebih kuat daripada persepsi hambatan, individu tersebut cenderung melakukan tindakan kesehatan preventif yang direkomendasikan.

\section{Saran}

Diperlukan intervensi untuk meningkatkan pengetahuan masyarakat dan menciptakan kesadaran yang berkelanjutan dalam upaya pencegahan Covid-19. Intervensi yang diberikan harus mempertimbangkan terkait strategi komunikasi yang tepat agar dapat menjangkau kelompok luas.

Intervensi juga perlu ditekankan pada upaya kontrol persepsi kerentanan dan persepsi keseriusan, demi menurunkan resiko terjadinya depresi maupun 
kecemasan pada ibu hamil selama pandemi. Pihak-pihak yang berhubungan dengan hasil penelitian ini perlu untuk tetap mempertimbangkan persepsi manfaat, isyarat untuk bertindak, persepsi hambatan, dan self-efficacy yang dimiliki masyarakat.

\section{UCAPAN TERIMAKASIH}

Peneliti mengucapkan terima kasih kepada BPPM Fakultas Kedokteran Universitas Brawijaya yang telah berkenan mendanai penelitian ini dan rekan-rekan keilmuan serta seluruh pihak atas keterlibatannya dalam penelitian ini.

\section{DAFTAR PUSTAKA}

Aenishaenslin, C., Michel, P., Ravel, A., Gern, L., Milord, F., Waaub, J.-P., \& Bélanger, D. (2015). Factors associated with preventive behaviors regarding Lyme disease in Canada and Switzerland: a comparative study. BMC Public Health, 15(1), 185. https:// doi.org/10.1186/s12889-015-1539-2

Aghababaei, S., Bashirian, S., Soltanian, A., Refaei, M., Omidi, T., Ghelichkhani, S., \& Soltani, F. (2020). Perceived risk and protective behaviors regarding COVID-19 among Iranian pregnant women. https:// doi.org/10.1186/s43043-020-00038-z

Badan Pusat Statistik. (2019). Istilah Statistik Kependudukan.

Barakat, A. M., \& Kasemy, Z. A. (2020). Preventive health behaviours during coronavirus disease 2019 pandemic based on health belief model among Egyptians. Middle East Current Psychiatry, 27(1). https://doi.org/ 10.1186/s43045-020-00051-y

Briet, J., McAuliffe, F., \& Baalman, J. (2020). Is termination of early pregnancy indicated in women with COVID-19? Correspondence/European Journal of Obstetrics \& Gynecology and Reproductive Biology, 251, 271-272.

Carolina Awad, D., Zaiter, A., Ghiya, P., Zaiter, K., Louka, J. G., Fakih, C., \& Chahine, M. N. (2020). COVID-19:
Pregnant Women's Knowledge, Perceptions \& Fears. First National Data from Lebanon. Obstetrics and Gynecology Research, 03(04), 220-234. https://doi.org/10.26502/ogr044

Coronavirus disease (COVID-19). (2020).

Ferrer, R., \& Klein, W. M. (2015). Risk perceptions and health behavior HHS Public Access. 5, 85-89. https://doi.org/ 10.1016/j.copsyc.2015.03.012

Glanz, K., Rimer, B. K., \& Viswanatah, K. (2008). Health behavior and health education: theory, research, and practice (K. Glanz, B. K. Rimer, \& K. Viswanatah (Eds.); fourth ed). JosseyBass.

Hakiki, G., \& Supriyanto, S. (2018). Profil Perempuan Indonesia 2018. In Kementerian Pemberdayaan Perempuan dan Perlindungan Anak.

Kementerian Kesehatan Republik Indonesia. (2014). Buku Saku Bagi Bidan/ Perawat Dan Kader Kesehatan Untuk Mendukung Pengembangan Desa Dan Kelurahan Siaga Aktif. Kementerian Kesehatan Republik Indonesia Pusat Promosi Kesehatan.

Kementerian Pemberdayaan Perempuan dan Perlindungan Anak. (2018). Profil Perempuan Indonesia 2018 (Badan Pusat Statistik (Ed.)). Kementerian Pemberdayaan Perempuan dan Perlindungan Anak.

Khazaeian, S, Khazaeian, S., \& Fathnezhad-kazemi, A. (2020). Pregnant women's knowledge, perceived severity, and perceived controllability of the COVID-19 and their associations with emotional and behavioral reactions: A cross-sectional study. ResearchSquare, 1-21. https:// doi.org/10.21203/rs.3.rs-132425/v1

Khazaeian, Somayyeh, \& Khazaeian, S. (2020). Pregnant women's knowledge, perceived severity, and perceived controllability of the COVID-19 and their associations with emotional and behavioral reactions.

LaMorte, W. W. (2019). Behavioral Change 
Models: The Health Belief Model. Boston University School of Public Health.

Londero, A. P., Rossetti, E., Pittini, C., Cagnacci, A., \& Driul, L. (2019). Maternal age and the risk of adverse pregnancy outcomes: A retrospective cohort study. BMC Pregnancy and Childbirth, 19(1), 1-10. https://doi.org/ 10.1186/s12884-019-2400-x

Mengesha Yalew, Z., Asmamaw Yitayew, Y., Seid Mohammed, E., \& Bezabih Gezihagne, T. (2021). Health Communication, Knowledge, Perception and Behavioral Responses to COVID-19 Outbreak in Dessie, Kombolcha and Kemissie Towns, Amhara Region, Northeast Ethiopia: A Mixed-Method Study. https://doi.org/10.2147/ JMDH.S309340

Mirzaei, A., Kazembeigi, F., Kakai, H., Mohsen Jalilian, Mazloomi, S., \& Nourmoradi, H. (2021). Application of health belief model to predict COVID19-preventive behaviors among a sample of Iranian adult population. Journal of Education and Health Promotion, 10(February), 1-7. https:// doi.org/10.4103/jehp.jehp

Mo, P. K. H., Fong, V. W. I., Song, B., Di, J., Wang, Q., \& Wang, L. (2021). Association of Perceived Threat, Negative Emotions, and Self-Efficacy With Mental Health and Personal Protective Behavior Among Chinese Pregnant Women During the COVID-19 Pandemic: Cross-sectional Survey Study. https://doi.org/ $10.2196 / 24053$

Nugrahani, R. R., Budihastuti, U. R., \& Pamungakasari, E. P. (2017). Health Belief Model on the Factors Associated With the Use of Hpv Vaccine for the Prevention of Cervical Cancer Among Women in Kediri, East Java. Journal of Epidemiology and Public Health, 2(1), 7881. https://doi.org/10.26911/ theicph.2017.009

Nurdianto, A. R., Nurdianto, R. F., \& Febiyanti, D. A. (2020). Infeksi COVID-19 pada kehamilan dengan insulin dependent diabetes mellitus (IDDM). Jurnal Ilmiah Kedokteran Wijaya Kusuma, 9(2), 229. https:// doi.org/10.30742/jikw.v9i2.966

Pemprov Jatim, S. C.-19. (2021). Peta Sebaran Covid-19 Jatim. Available from: https://infocovid19.jatimprov.go.id/

Diakses tanggal 17 Juni 2021

Peraturan Pemerintah Republik Indonesia Nomor 47 Tahun 2008 Tentang Wajib Belajar, (2008) (testimony of Peraturan Pemerintah Republik Indonesia).

Pontoh, A. (2016). Tingkat Karakteristik (Umur, Paritas, Pendidikan) Ibu Hamil Tentang Kejadian Kehamilan Resiko Tinggi. Akademi Kebidanan Griya Husada, 52-59.

PP POGI. (2020). Rekomendasi Penanganan Infeksi Virus Corona (Covid-19). In Maret.

Satgas COVID-19. (2021). Data Sebaran Covid-19 Global dan Indonesia. Available from: https:// infocovid19.jatimprov.go.id/ Diakses tanggal 17 Juni 2021

Shahnazi, H., Ahmadi-Livani, M., Pahlavanzadeh, B., Rajabi, A., Hamrah, M. S., \& Charkazi, A. (2020). Assessing preventive health behaviors from COVID-19: a cross sectional study with health belief model in Golestan Province, Northern of Iran. Infectious Diseases of Poverty, 9(1), 1-9. https://doi.org/10.1186/s40249-02000776-2

Susilo, A., Rumende, C. M., Pitoyo, C. W., Santoso, W. D., Yulianti, M., Herikurniawan, H., Sinto, R., Singh, G., Nainggolan, L., Nelwan, E. J., Chen, L. K., Widhani, A., Wijaya, E., Wicaksana, B., Maksum, M., Annisa, F., Jasirwan, C. O. M., \& Yunihastuti, E. (2020). Coronavirus Disease 2019: Tinjauan Literatur Terkini. Jurnal Penyakit Dalam Indonesia, 7(1), 45. https://doi.org/10.7454/jpdi.v7i1.415

Yang, P., Wang, X., Liu, P., Wei, C., He, B., Zheng, J., \& Zhao, D. (2020). Clinical characteristics and risk assessment of 
newborns born to mothers with

COVID-19. Journal of Clinical Virology, 127(January), 104356. https://doi.org/ 10.1016/j.jcv.2020.104356

Yehualashet, S. S., Asefa, K. K., Mekonnen, A. G., Gemeda, B. N., Shiferaw, W. S., Aynalem, Y. A., Bilchut, A. H., Derseh, B. T., Mekuria, A. D., Mekonnen, W. N., Meseret, W. A., Tegegnework, S. S.,
\& Abosetegn, A. E. (2021). Predictors of adherence to COVID-19 prevention measure among communities in North Shoa Zone, Ethiopia based on health belief model: A cross-sectional study. Plos One Collection Social Psychiatry. https://doi.org/https:// doi.org/10.1371/journal.pone.0246006 